\title{
Purifikasi dan Karakterisasi Krom Reduktase Bacillus sp LKA9
}

\section{Purification and Characterization of Bacillus sp LKA9 Chromate Reductase}

\author{
Alimuddin Ali ${ }^{1}$, Endang Sutariningsih Soetarto ${ }^{2}$, J. Sri Widada $^{3}$ \\ ${ }^{1}$ Jurusan Biologi FMIPA Universitas Negeri Makassar, Jl. Dg Tata Raya Parangtambung, Makassar \\ Telp: (0411) 840610, Fax: (0411) 841504 E-mail: muddin_wbk02@yahoo.com *Penulis untuk korespondensi \\ ${ }^{2}$ Laboratorium Mikrobiologi Fakultas Biologi UGM Yogyakarta \\ ${ }^{3}$ Directeur de Recherche au C.N.R.S Universit'e Montpellier, Perancis
}

\begin{abstract}
Chromate reductase is one of the potential enzymes for hexavalent chrom detoxification. Most of the enzyme is produced by bacteria, especially Bacillus. The aim of this research was to study chromate reductase activity isolated from Bacillus sp LKA9. Bacillus sp LKA9 was isolated from leather tannery liquid waste and used as a model in the experiment. Bacillus sp LKA9 was isolated through enrichment culture using Salt Base Solution containing $3 \mathrm{mM} \mathrm{K}_{2} \mathrm{CrO}_{4}$. Chromate reductase was isolated from bacteria by growing on a liquid medium containing chrom hexavalen (Cr VI) through several steps. The first step of the isolation process was to use the precipitated process using ammonium sulphate $(30-80 \%)$. The next step, crude enzymes from the first step was partially purified through DEAE-Cellulose of Ion Exchange Chromatography Column. Diphenylcarbazide methods was used to examine the activity of enzyme fractions. The result of the experiment revealed that all protein could be precipitated by ammonium sulphate, and the cytoplasmic fraction at saturation of 5070\% showed high enzyme activity. Purified enzymes showed an increase activity 69,385 times to that of crude enzymes. The enzyme optimal had temperature and $\mathrm{pH}$ were $35^{\circ} \mathrm{C}$ and 5; respectively. $K_{M}$ of enzyme was $0,0075 \mathrm{mM}$, and $V_{\max }$ was 2500 $\mu \mathrm{mol} / \mathrm{minute} / \mathrm{mg}$ protein. Enzyme activity was not inhibited by $\mathrm{Cu}^{2+}$, but an ion $\mathrm{Ag}^{2+}$ and $\mathrm{Hg}^{2+}$ inhibited the enzyme activity un-competitive. The activity of enzyme was demonstrated on SDS-PAGE by appearing typically band with molecular weight 29,26 $\mathrm{kDa}$, it was assumed as chromate reductase.
\end{abstract}

Keywords: Chromate reductase, Bacillus sp LKA9, activated sludge, leather tannery industries liquid waste

Diterima: 10 September 2005, disetujui: 27 Januari 2006

\section{Pendahuluan}

Krom merupakan salah satu logam berat yang banyak digunakan dalam industri misalnya industri penyamakan kulit, elektroplating (Krauter et al., 1996), pembuatan logam anti karat, pembuatan pestisida, oksidan, katalis, pengolahan kayu dan sebagainya (Baldi et al., 1990). Meskipun krom merupakan senyawa yang sangat penting bagi nutrisi manusia utamanya krom trivalen, akan tetapi krom hexavalen $\left(\mathrm{Cr}^{6+}, \mathrm{CrO}_{4}{ }^{2+}\right.$,
$\mathrm{Cr}_{2} \mathrm{O}_{7}{ }^{2+}$ ) justru bersifat toksik pada manusia, hewan maupun tanaman (Fude et al., 1994) dan mutagenik pada bakteri dan fungi (Baldi et al., 1990).

Pengolahan limbah yang mengandung krom masih menggunakan cara fisika-kimia yang membutuhkan peralatan dan sistem monitoring yang mahal. Secara konvensional dilakukan melalui reduksi kimia dan selanjutnya dilakukan proses presipitasi, adsorpsi dengan karbon aktif dan sebagainya (Ohtake et al., 1987). Cara tersebut berpotensi 
memunculkan terbentuknya sumber limbah baru (Garbisu et al., 1998)

Beberapa mikrobia yang resisten terhadap krom telah dipelajari kemampuan reduksinya antara lain Pseudomonas aeroginosa (Ganguli \& Tripathi, 1999), Pseudomonas sp CRB5 (McLean et al., 1999), Pseudomonas putida (Park et al., 2000), Enterobacter sp (Wang et al., 1990), Alcaligenes eutrophus (Peitzch et al., 1998) dan Saccharomyces cereviceae (Krauter et al., 1996). Kemampuan mikrobia mereduksi krom tersebut berbeda-beda antara satu mikrobia dengan mikrobia lainnya. Menurut Ishibashi et al., 1990 dan Cervantes et al., 2001 mekanisme reduksi krom $\mathrm{Cr}^{6+}$ merupakan metode yang sangat potensial diterapkan dalam proses detoksifikasi dan bioremediasi

Dalam kondisi lingkungan kurang menguntungkan, beberapa mikrobia tanggap atau mampu bertahan dan berkembang biak. Populasi mikrobia alami ini dapat menggambarkan kondisi lingkungan mikrobia secara lebih akurat. Dengan demikian dapat dinyatakan bahwa populasi mikrobia dapat digunakan untuk memperkirakan keberadaan logam-logam polutan dalam suatu lingkungan (Hughes \& Poole, 1989). Berdasarkan hal tersebut beberapa mikrobia yang memiliki potensi bioremediasi seperti biosorpsi, akumulasi dan reduksi krom dapat diisolasi dari lingkungan alami. Mikrobia yang berpotensi sebagai bioremediator misalnya kemampuan melakukan reduksi krom dapat dipelajari melalui aktivitas enzimnya, baik secara in vitro maupun in vivo. Penelitian ini bertujuan untuk mempelajari aktivitas krom reduktase dari bakteri yang diisolasi dari limbah penyamakan kulit. Pengujian aktivitas enzim ini dilakukan untuk menentukan spesifikasi, aktivitas optimum dan lokasi enzim bakteri tersebut (sitoplasmik, membran sitoplasmik atau ekstraselluler).

\section{Metode Penelitian}

\section{Isolasi bakteri}

Bacillus sp LKA9 diisolasi dari lumpur cair aktif bak pengolahan limbah penyamakan kulit PT. Budi Makmur Yogyakarta. Isolasi bakteri dilakukan dengan menggunakan teknik kultur diperkaya dalam medium Salt Base Solution (modifikasi) berdasarkan metode Garbisu et al., 1998 yang mengandung ( $\mathrm{g} / \mathrm{L})$ : $\mathrm{K}_{2} \mathrm{HPO}_{4}(1,5), \mathrm{KH}_{2} \mathrm{PO}_{4}(0,5),\left(\mathrm{NH}_{4}\right)_{2} \mathrm{SO}_{4}(0,5)$, $\mathrm{MgSO}_{4} \cdot 7 \mathrm{H}_{2} \mathrm{O}(0,2)$ dan pancreatic digest of gelatin $(5,0)$, beef extract (15), dan glukosa (1) agar (15), $\mathrm{pH}$ media diatur menjadi 6,8 $\pm 0,2$. Media isolasi tersebut ditambahkan $3 \mathrm{mM}$ $\mathrm{K}_{2} \mathrm{CrO}_{4}$. Sebanyak $1 \mathrm{~mL}$ lumpur cair aktif diinokulasikan ke dalam $100 \mathrm{~mL}$ media SBS, lalu diberi kejutan panas di dalam waterbath pada suhu $70^{\circ} \mathrm{C}$ selama 10 menit. Selanjutnya 1 $\mathrm{mL}$ diinokulasikan ke dalam medium Blood Agar secara tuang. Koloni yang tumbuh dilakukan karakterisasi berdasarkan prosedur Holt et al., 1994.

\section{Uji kemampuan tumbuh bakteri terhadap krom}

Isolat (Bacillus sp LKA9) yang diperoleh diuji kemampuan tumbuhnya terhadap krom. Sebanyak $5 \mathrm{~mL}$ inokulum ditumbuhkan ke dalam $150 \mathrm{~mL}$ medium SBS yang mengandung masing-masing 0,5 sampai 8 $\mathrm{mM} \mathrm{K}_{2} \mathrm{CrO}_{4}$. Selanjutnya diinkubasi selama 24 jam pada suhu $37^{\circ} \mathrm{C}$ dalam orbital shaker dengan kecepatan 150 rpm. Pertumbuhan diamati dengan mengukur absorbansi $\left(\mathrm{A}_{600 \mathrm{~nm}}\right)$ dalam interval waktu 2 jam. Semua pelaksanaan sampling pada perlakuan diatas dipantau dengan mengukur viable cell count (CFU/ml) pada media SBS Agar (Garbisu et al., 1998). Pengujian yang sama dilakukan pada media yang diinokulasikan Eschericia sp yang sensitif krom sebagai pembanding.

\section{Uji kemampuan reduksi krom dari Bacillus sp LKA 9}

Isolat ditumbuhkan pada medium SBS yang mengandung $2 \mathrm{mM} \mathrm{K}_{2} \mathrm{CrO}_{4}$. Pengukuran kemampuan reduksi krom dilakukan berdasarkan metode difenilkarbazid menurut petunjuk Garbisu et al., 1998 pada setiap interval waktu 4 jam. Pengamatan pertumbuhan bakteri dilakukan dengan pengukuran absorbansi medium tumbuh ( $\mathrm{A}_{600}$ $\mathrm{nm})$. 


\section{Isolasi Krom Reduktase}

\section{Fraksi ekstraselluler}

Isolat bakteri ditumbuhkan dalam 150 $\mathrm{mL}$ medium SBS yang mengandung krom 2 $\mathrm{mM}$ pada suhu $37^{\circ} \mathrm{C}$ selama 24 jam. Sel diunduh lalu disentrifuse pada kecepatan 5000 rpm selama 15 menit. Supernatan didekantasi lalu diuji aktivitas krom reduktasenya.

\section{Fraksi sitoplasmik (cell free extract)}

Pellet (biomassa bakteri) dicuci dua kali dengan Tris-HCL $10 \mathrm{mM}$ plus EDTA $2 \mathrm{mM}$ pH 7,4. Disentrifuse kembali pada kecepatan $5000 \mathrm{rpm}$ selama 15 menit dan supernatan dibuang. Pellet diresuspensi 1/10 dari volume awal dengan buffer yang sama. Selanjutnya pellet dipecah dengan menggunakan ultrasonikator (Labsonic-U Braun) $14 \mathrm{~m}$ amplitudo selama 5 kali 30 detik pulsa. Homogenat yang diperoleh disentrifuse pada kecepatan $10.000 \mathrm{x}$ g selama 15 menit pada suhu $4^{0} \mathrm{C}$ dan disebut fraksi sitoplasmik (Bollag et al., 1996)

\section{Fraksi membran sitoplasmik}

Pellet hasil preparasi fraksi sitoplasmik diresuspensi dalam $1 \mathrm{~mL} \mathrm{0,5 \%} \mathrm{(v/v)} \mathrm{Nonidet}$ P-40 dalam buffer Tris-HCl-EDTA. Suspensi yang diperoleh distirrer semalam pada suhu $4^{0} \mathrm{C}$. Selanjutnya disentrifuse pada kecepatan $10.000 \times$ x selama 20 menit pada suhu $4^{0} \mathrm{C}$. Supernatan yang diperoleh, didialisis semalam dalam buffer Tris-HCl plus EDTA pada suhu $4^{0} \mathrm{C}$.

\section{Fraksinasi dengan presipitasi amonium sulfat}

Enzim kasar yang diperoleh pada setiap tahap isolasi selanjutnya dilakukan presipitasi dengan menggunakan ammonium sulfat (20$80 \%$ ). Masing-masing fraksi didialisis dalam buffer yang sama. Selanjutnya diuji aktivitas krom reduktasenya (Ishibasi et al., 1990) dan ditetapkan kadar proteinnya menurut metode Braford (1976). Satu unit aktivitas enzim dalam penelitian ini adalah sejumlah enzim yang diperlukan untuk mengubah $1 \mu \mathrm{mol}$ substrat krom (VI)/ml/menit. Aktivitas spesifiknya dihitung sebagai unit enzim/menit/mg protein.

\section{Fraksinasi kolom kromatografi DEAE- Cellulose penukar ion}

Kolom kromatografi diekuilibrasi dengan larutan $0,5 \mathrm{M} \mathrm{NaCl}$, lalu dibilas dengan buffer $10 \mathrm{mM}$ Tris $\mathrm{HCl}$ plus EDTA $2 \mathrm{mM} \mathrm{pH}$ 7,4 . Sebanyak $1 \mathrm{~mL}$ hasil fraksinasi ammonium sulfat yang mengandung $1,76 \mathrm{mg}$ protein difraksinasi pada kolom DEAE-Cellulosa. Selanjutnya dilakukan optimasi waktu dan laju aliran fraksi. Kolom dielusi dengan gradien 0,1 $-0,5 \mathrm{M} \mathrm{NaCl}$ masing-masing sebanyak $50 \mathrm{~mL}$. Laju elusi 1,5 mL/10 menit. Semua fraksi ditampung dalam tabung reaksi mini collector dan diukur absorbansinya pada panjang gelombang $280 \mathrm{~nm}$ dengan menggunakan spektrofotometer Beckman (digunakan sebanyak $100 \mu \mathrm{L})$.

\section{Karakterisasi enzim}

Karakterisasi enzim dilakukan meliputi: penentuan $\mathrm{pH}$ dan suhu optimum, penentuan nilai $\mathrm{K}_{M}$ dan $\mathrm{V}_{\text {maks }}$ enzim serta pengaruh zat inhibitor $\left(\mathrm{HgCl}_{2}, \mathrm{Ag}_{2} \mathrm{SO}_{4}, \mathrm{CuSO}_{4}\right)$. Penentuan kinetika mengacu pada metode Atkin dan Nimmo, (1980).

\section{Visualisasi profil protein secara SDS- PAGE}

Visualisasi profil protein dilakukan berdasarkan petunjuk Renee, 1993. Sebanyak $50 \mu \mathrm{L}$ enzim ditambahkan $12,4 \mu \mathrm{L}$ buffer sample. Campuran larutan tersebut dipanaskan dalam air mendidih selama 2 menit. Selanjutnya didinginkan secepatnya dalam es. Sample diloading dalam sumuran elektroforesis. Proses elektroforesis dilakukan selama 60 menit, kemudian dilakukan pewarnaan dengan Coomassie Blue 0,2\%. Sebagai marker digunakan antara lain; Bovine serum albumin (66.000 Da); L-glutamic dehydrogenase $(55.000 \mathrm{Da}) ; \quad$ ovalbumin (42.700 Da); Aldolase (40.000 Da); Carbonic anhydrase (31.000 Da); Soybean trypsin inhibitor (21.500 Da) (Promega Mid-Ranger Protein MW Marker, V5234). 


\section{Hasil dan Pembahasan}

\section{Kemampuan Tumbuh Bacillus sp LKA9 terhadap Krom}

Kemampuan tumbuh bakteri pada medium yang mengandung krom menunjukkan bahwa Bacillus sp LKA9 mampu tumbuh

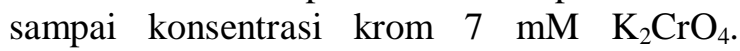

Kemampuan tumbuh isolat ini lebih tinggi dibanding dengan Escherichia sp (bakteri pembanding), yang hanya mampu tumbuh pada konsentrasi 1,5 mM. Kemampuan Bacillus sp LKA9 masih lebih tinggi dibanding Bacillus subtilis yang hanya mampu tumbuh pada konsentrasi $1 \mathrm{mM}$ seperti yang dilaporkan oleh Garbisu et al., 1998.

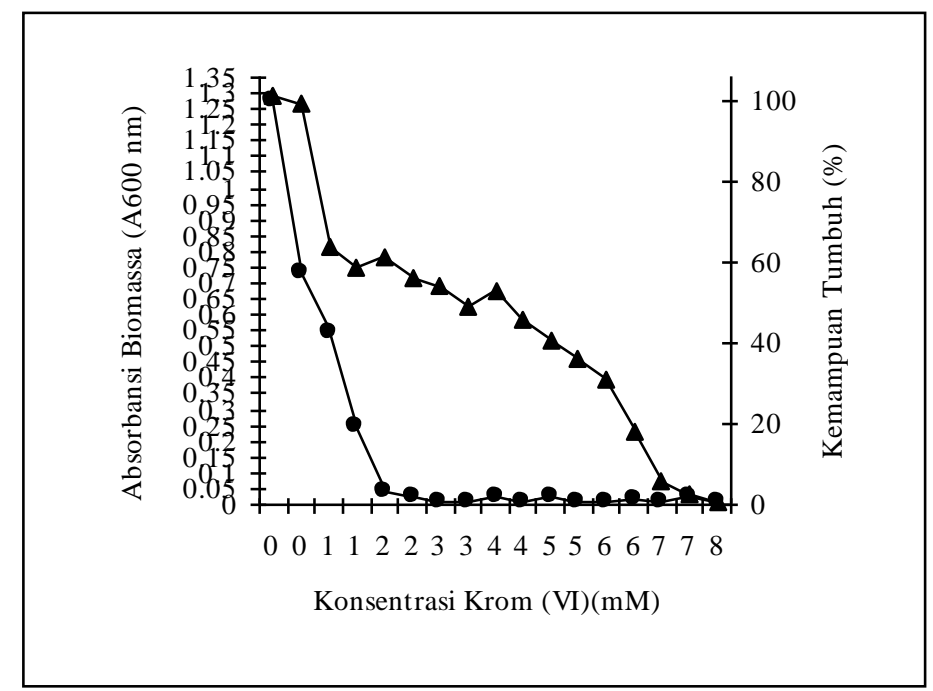

Gambar 1. Kemampuan tumbuh Bacillus sp LKA9(-- - --) dan

Escherichia sp sebagai pembanding (-- --)

Pada konsentrasi 3,5 mM kemampuan tumbuh Bacillus sp LKA9 berkurang secara drastis mencapai dibawah 50\%. Konsentrasi krom sampai batas 4,5 $\mathrm{mM}$ menyebabkan bakteri masih mampu tumbuh mencapai $40 \%$ sehingga dinyatakan sebagai zone resistensi aktif. Selanjutnya konsentrasi yang lebih tinggi dari 4,5 mM kemampuan ini sangat rendah yaitu dibawah 20\%, sehingga dinyatakan sebagai konsentrasi toksik (Kiefer, 2000)

Kemampuan tumbuh yang cukup tinggi terhadap krom pada bakteri konsorsium atau gabungan bakteri pereduksi sulfat (SRB III) juga telah dilaporkan (Fude et al., 1994). Mikrobia tersebut mampu tumbuh pada konsentrasi krom 2500 ppm $(48,077 \mathrm{mM})$. Kemampuan tumbuh bakteri ini hampir tujuh kali lipat dari isolat Bacillus sp LKA9. Hal ini disebabkan oleh beragamnya sifat yang dimiliki oleh gabungan bakteri tersebut, sehingga terjadi interaksi (sinergi) yang saling mempengaruhi antara satu dengan lainnya.

\section{Uji kemampuan reduksi Bacillus sp LKA 9 terhadap krom}

Kemampuan Bacillus sp LKA9 mereduksi krom dengan sel utuh (whole cells) ditunjukkan pada Gambar 2. Reduksi krom setelah 8 jam masa inkubasi mencapai $10 \%$ dari konsentrasi krom awal dan pada 12 jam, reduksi mencapai $45 \%$, dan makin menurun setelah 12 jam. Rendahnya aktivitas reduksi setelah 12 jam terkait dengan konsentrasi krom VI makin kecil. Konsentrasi krom toksik yang rendah tersebut tidak akan mengganggu aktivitas metabolisme bakteri secara nyata. Menurut Shen dan Wang (1993), mekanisme reduksi krom merupakan proses kometabolisme, yaitu krom berfungsi sebagai akseptor elektron kompetitif melalui rantai transpor elektron. Kiefer, (2000) menambahkan bahwa mekanisme lainnya diantaranya akumulasi krom (VI) dalam sel, penyerapan (uptake) atau pengikatan krom pada membran sitoplasma sel mikrobia. 


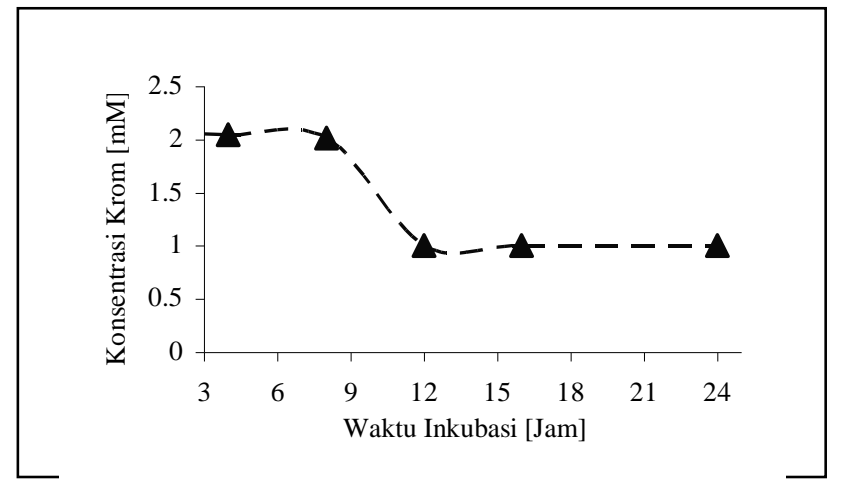

Gambar 2. Kemampuan reduksı krom darı Bacıllus sp LKA9 dengan lama inkubasi

\section{Hasil purifikasi krom reduktase dengan kolom kromatografi penukar ion DEAE- Cellulose}

$\begin{array}{ccc}\text { Hasil purifikasi sebagian dari krom } \\ \text { reduktase } & \text { melalui fraksinasi dengan }\end{array}$ menggunakan kolom kromatografi penukar

Tabel 1. Tahapan fraksinasi, aktivitas enzim dan purifikasi krom reduktase Bacillus sp LKA9

\begin{tabular}{|c|c|c|c|c|c|c|c|c|}
\hline \multirow{2}{*}{ "Hasil Fraksinasi } & \multirow{2}{*}{$\begin{array}{l}\text { Volum } \\
(\mathrm{mL})\end{array}$} & \multicolumn{2}{|c|}{ Protein } & \multicolumn{3}{|c|}{ Aktivitas enzim } & \multirow{2}{*}{$\begin{array}{c}\text { Yield } \\
(\%)\end{array}$} & \multirow{2}{*}{$\begin{array}{l}\text { Kelipatan } \\
\text { purifikasi }\end{array}$} \\
\hline & & $\begin{array}{c}\mathbf{m g} / \\
\mathbf{m L}\end{array}$ & $\begin{array}{r}\mathrm{Mg} \\
\text { total }\end{array}$ & $\begin{array}{c}\text { Unit/ } \\
\text { mL }\end{array}$ & $\begin{array}{c}\text { Spesifik } \\
\text { (unit/mg protein) }\end{array}$ & $\begin{array}{l}\text { Unit } \\
\text { total }\end{array}$ & & \\
\hline Crude enzim & 15 & 1,0250 & 15,375 & 3,214 & 3,1356 & 48,210 & 100 & 1 \\
\hline Amm.sulfat (50-70\%) & 8 & 0,2195 & 1,756 & 6,187 & 28,1867 & 1,358 & 2,817 & 8,989 \\
\hline $\begin{array}{l}\text { Fraksinasi Kolom DEAE- } \\
\text { Cellulosa }\end{array}$ & 4,5 & 0,0353 & 0,159 & 7,680 & 217,564 & 34,560 & 71,686 & 69,385 \\
\hline
\end{tabular}

Tingkat purifikasi ini masih lebih rendah dari krom reduktase Pseudomonas putida yang mencapai 18,6 kali dari ekstrak kasarnya (Park et al., 2000). Namun demikian penggunaan matrik DEAE-Cellulose masih
ion-DEAE-Cellulose menunjukan aktivitas spesifik meningkat dari 3,1356 unit/mg protein menjadi 217, 564 unit/mg protein. Tingkat purifikasi mencapai 69,386 kali dari crude enzim/ekstrak kasarnya (Tabel 1).

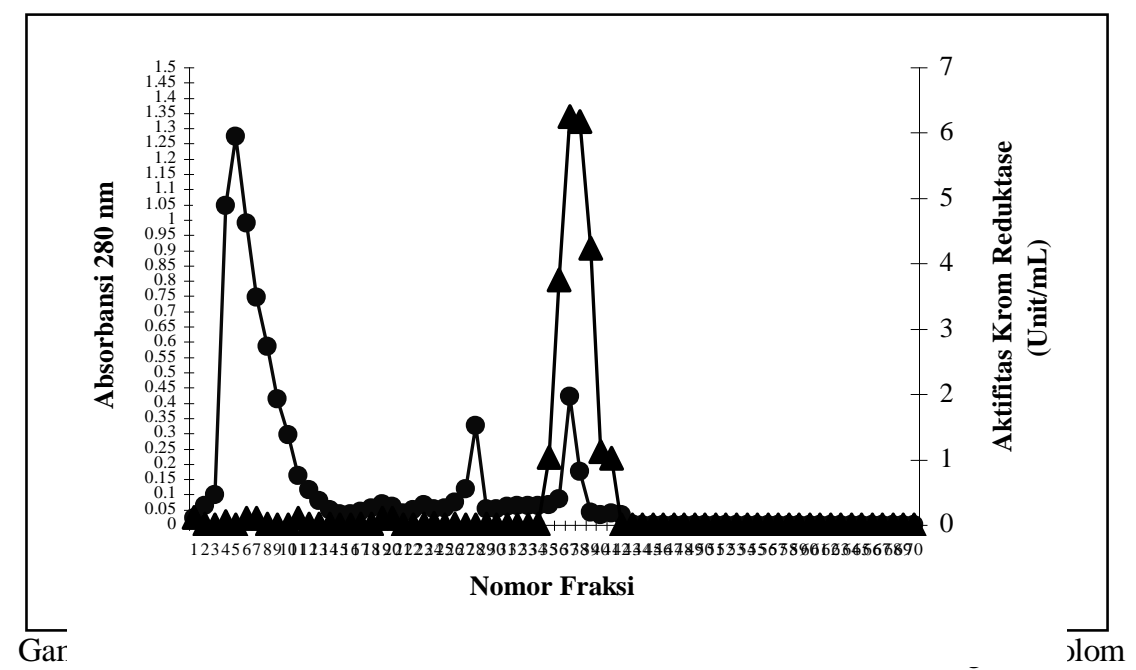

kromatografi DEAE-Cellulose (--•--) dan aktivitas krom reduktase (-- --) Bacillus sp LKA9 dari fraksi sitoplasmik dengan tingkat kejenuhan $50-70 \%$. 
Gambar tersebut menunjukkan pola serapan protein hasil fraksinasi pada panjang gelombang $280 \mathrm{~nm}$ dan terdiri dari 3 puncak (peak). Kedua puncak (I dan II) setelah diuji tidak menunjukkan aktivitas krom reduktase. Aktivitas enzim hanya ditunjukkan oleh pada puncak ketiga yaitu fraksi nomor 35-38, diduga krom reduktase. Keadaan tersebut sesuai dengan percobaan yang ditunjukkan oleh Park et al., 2000. Namun sebaliknya berbeda dengan faktor elusi garam yang kurang dari $0,1 \mathrm{M}$ $\mathrm{NaCl}$. Pola serapan protein hasil fraksinasi tersebut menunjukkan adanya protein non enzim yang terelusi dalam jumlah besar.

\section{Pengaruh pH dan Suhu terhadap Aktivitas Krom Reduktase}

Aktivitas krom reduktase dipengaruhi oleh suhu dan $\mathrm{pH}$. Enzim tersebut mempunyai $\mathrm{pH}$ optimum sekitar $\mathrm{pH} 5$ dengan aktivitas $142,476 \mu \mathrm{mol} / \mathrm{menit} / \mathrm{mg}$ protein. Aktivitas krom reduktase pada $\mathrm{pH} 9$ mencapai 52,190 $\mu \mathrm{mol} / \mathrm{menit} / \mathrm{mg}$ protein jauh lebih rendah dari $\mathrm{pH}$ optimum.

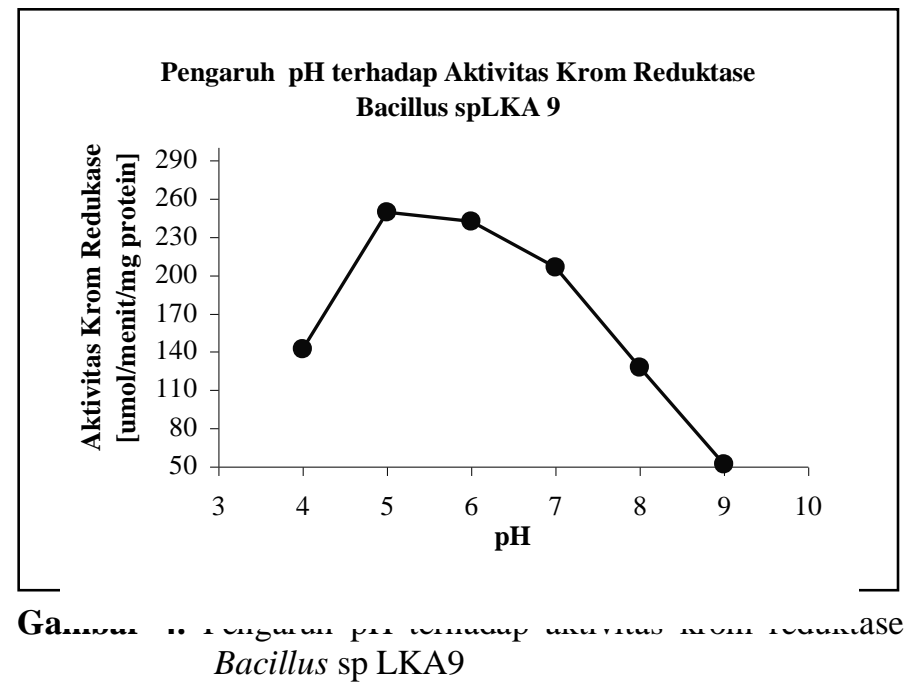

Aktivitas tertinggi ditunjukkan sekitar (217,564 $\mu \mathrm{mol} / \mathrm{menit} / \mathrm{mg}$ protein) pada suhu $35^{\circ} \mathrm{C}$. Secara keseluruhan krom reduktase yang pernah dilaporkan mempunyai aktivitas optimum pada kisaran $\mathrm{pH} 5$ sampai 7 antara lain pH 5 pada Pseudomonas putida (Park et al., 2000); pH 6,5 pada Pseudomonas sp (Ishibashi et al., 1990); dan $\mathrm{pH} 7,0$ pada Bacillus sp QC $\mathrm{QC}_{1-2}$ (Campos et al., 1997).

Aktivitas krom reduktase yang diperlakukan pada berbagai aras suhu tercantum pada Gambar 5.

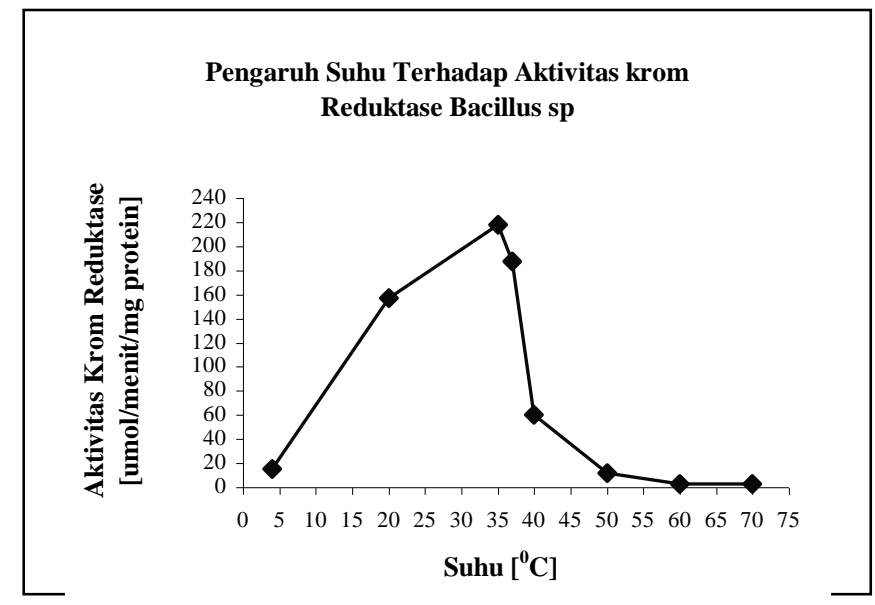

Gambar 5. Pengaruh suhu terhadap aktıvitas krom reduktase Bacillus sp LKA9 
Pengaruh suhu terhadap aktivitas enzim cukup variatif. Aktivitas tertinggi mencapai $(217,564 \mu \mathrm{mol} / \mathrm{menit} / \mathrm{mg}$ protein) pada suhu $35^{\circ} \mathrm{C}$, menurun dengan meningkatnya suhu inkubasi. Bila mengacu pada beberapa penelitian yang telah dilaporkan, suhu aktivitas reduktase optimum Bacillus sp LKA9 cukup rendah. Suhu optimum ini sama dengan suhu optimum Escherichia coli ATCC (Shen dan Wang, 1993). Suhu optimum krom reduktase Bacillus sp $\mathrm{QC}_{1-2}$ mencapai $37^{\circ} \mathrm{C}$ (Campos et al., 1997); bahkan Pseudomonas putida yang dilaporkan Park et al., 2000 mencapai suhu optimum $80^{\circ} \mathrm{C}$. Meskipun diketahui bahwa genus Bacillus sp umumnya memiliki enzim termofilik, namun hal ini lebih dominan disebabkan oleh sifat enzim sitoplasmik yang sangat peka terhadap suhu tinggi.

\section{Kinetika reaksi dan pengaruh senyawa inhibitor krom reduktase}

Berdasarkan data kinetika percobaan yang diperoleh diketahui bahwa kecepatan maksimal $\left(\mathrm{V}_{\text {maks }}\right)$ adalah $2500 \mu \mathrm{mol} / \mathrm{menit} / \mathrm{mg}$ protein dan konstanta Michaelis-Menten $\left(\mathrm{K}_{M}\right)$ adalah 0,0075 mM. Nilai ini diestimasi dari persamaan Lineaweaver-Burk. Affinitas ini lebih tinggi bila dibanding krom reduktase yang dilaporkan oleh peneliti sebelumnya.
Hasil penelitian menunjukkan bahwa $\mathrm{Cu}^{2+}\left(\mathrm{CuSO}_{4}\right)$ tidak menghambat aktivitas krom reduktase Bacillus sp LKA9 sampai $0,005 \mathrm{mM}$. Hal ini terlihat dari nilai $\mathrm{V}_{\text {maks }}$ enzim tidak berubah (tetap). Berdasarkan hasil uji pengaruh $\mathrm{Ag}^{2+}$ dan $\mathrm{Hg}^{2+}$ diketahu bahwa ion $\mathrm{Ag}^{2+}$ dan $\mathrm{Hg}^{2+}$ menghambat aktivitas krom reduktase Bacillus sp LKA9. Hal ini nampak dari nilai $\mathrm{V}_{\text {maks }}$ perlakuan dengan senyawa penghambat yang diperoleh lebih rendah dari $\mathrm{V}_{\text {maks }}$ tanpa $\mathrm{Ag}^{2+}$ dan $\mathrm{Hg}^{2+}$. Ini mengindikasikan bahwa kedua logam tersebut menghambat aktivitas krom reduktase secara un-kompetitif. Pengaruh penghambatan $\mathrm{Hg}^{2+}$ lebih kuat dibanding dengan $\mathrm{Ag}^{2+}$. Hal ini nampak dari perbedaan nilai $\mathrm{V}_{\text {maks }}$ kedua ion tersebut mencapai 2,6 kali lipat.

\section{Visualisasi profil protein secara SDS- PAGE}

Hasil visualisasi profil protein menunjukkan adanya lebih dari satu pita dengan BM yang berbeda seperti yang terlihat pada Gambar 6. Ini menunjukkan bahwa pemisahan dengan kolom kromatografi yang dilakukan belum optimal. Untuk itu metode pemisahan tidak dapat dilakukan dengan menggunakan satu macam kolom kromatografi saja.

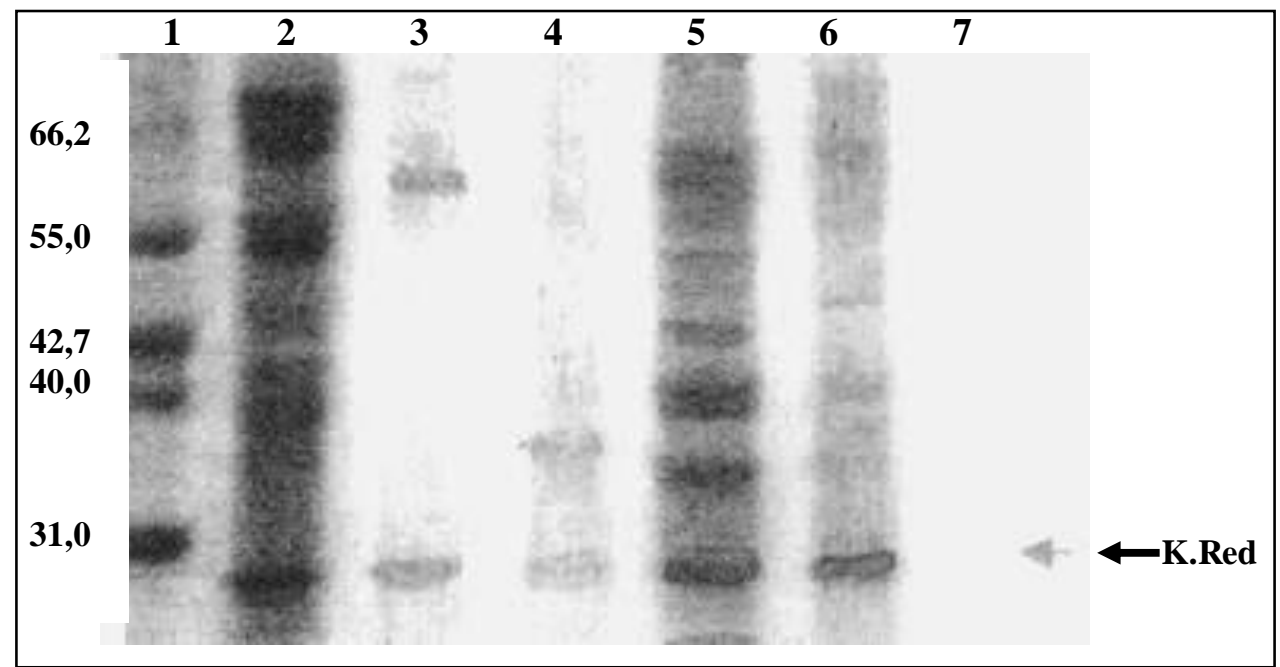

Gambar 6. Profil protein SDS PAGE 10\% hasil fraksinasi. Lajur1: Marker, lajur 2: Fraksi sitoplasmik hasil fraksinasi ammonium sulfat (50-70\%), lajur 3: Hasil elusi kolom kromatografi fraksi ke-37, lajur 4: Hasil elusi kolom kromatografi fraksi ke-38 dan 39, lajur 5: Membran sitoplasmik hasil fraksinasi ammonium sulfat 50-70\%, lajur 6: Membran sitopasmik hasil fraksinasi ammonium sulfat 20$50 \%$, lajur 7: Esktraselluler (supernatan media tumbuh). 
Dua sampel yang digunakan masingmasing adalah membran sitoplasma dengan presipitasi $50-70 \%$ dan $20-50 \%$ menunjukkan pola pita yang sama. Ini menunjukkan bahwa krom reduktase tidak hanya ada pada fraksi sitoplasmik tetapi terdapat pula pada membran sitoplasma.

Jika dilakukan perbandingan aktivitas krom reduktase pada fraksi sitoplasma dengan membran sitoplasma, maka kedua pita tersebut menunjukkan ketebalan pita yang berbeda. Hal ini terlihat dari aktivitas krom reduktase dari fraksi sitoplasma lebih tinggi dari membran sitoplasma. Sebaliknya pada fraksi ekstraselluler memperlihatkan pula satu pita yang kurang jelas. Namun letak pita ini tidak sama dengan pola pita fraksi lainnya. Ini menunjukkan bahwa krom reduktase hampir tidak ada yang disekresikan keluar sel.

Umumnya berat molekul krom reduktase yang pernah dilaporkan sebelumnya berada pada kisaran 20 - $40 \mathrm{kDa}$, maka dapat dikatakan bahwa berat molekul krom reduktase Bacillus sp LKA9 berkisar 29, 26 kDa Campos et al., 1997.

\section{Kesimpulan}

Berdasarkan hasil penelitian dapat disimpulkan bahwa Bacillus sp LKA9 mampu tumbuh pada konsentrasi $7 \mathrm{mM}$. Suhu dan $\mathrm{pH}$ optimum aktivitas krom reduktase masingmasing $35^{\circ} \mathrm{C}$ dan 5 . Kelipatan purifikasi mencapai 69,385 kali dari enzim kasarnya. Nilai $\left(\mathrm{K}_{M}\right)$ dan $\left(\mathrm{V}_{\text {maks }}\right)$ enzim berturut-turut $0,0075 \mathrm{mM}$ dan $2500 \mu \mathrm{mol} / \mathrm{menit} / \mathrm{mg}$ protein. Aktivitas krom reduktase tidak dihambat oleh $\mathrm{Cu}^{2+}$ tetapi dihambat oleh $\mathrm{Ag}^{2+}$ dan $\mathrm{Hg}^{2+}$ inkompetitif. Krom reduktase Bacillus sp LKA9 mempunyai berat molekul berkisar 29,26 kDa.

\section{Daftar Pustaka}

Atkin, G.L. and Nimmo, I.A. 1980. Current Trends in The Estimation of Michaelis-Menten Parameter. Anal. Biochem 104: 1-9.

Baldi, F., Vaugham, A.M. and Olson, G.J. 1990. Chromium (VI) Resistance Yeast Isolated from a Sewage treatment Plant Receiving Tannery Wastes. Appl. Environ. Microbiol. 56 (4): 913-918.
Bollag, D.M., Rozycki, M.D. and Edelstein, S.J. 1996. Protein Methods. $2^{\text {nd }}$ Edition. John Wiley and Sons Publication. New York.

Braford, M. 1976. A Rapid and Sensitive Method for the Quantitation of Microgram Quantities of Protein Utilizing the Protein-dye Binding. Anal Biochem 72:248-254

Campos, J., Martinez-Pocheco, M. and Cervantes, C. 1997. Hexavalent-Chromium Reduction by a Chromate Resistant Bacillus sp. Strain. Antonie Van Leuwenhoek. 68: 203 - 208.

Cervantes, C., Campos, J., Devans, S., Gutierez, F., Loza, H., Torres, T.C. and Moreno, R. 2001. Interactions of Chromium with Microorganism and Plant, FEMS Microbiology Reviews, 2: 133-141.

Fude, Li., Harris, B., Urrutia, M.M. and Beveridge,T.J. 1994. Reduction of Cr (VI) by a Consortium of Sulfate Reducing Bacteria (SRB III). Appl. Environ. Microbiol. 60: 1525 - 1531.

Ganguli, A. and Tripathi, A.K. 1999. Survival and Chromate Reducing Ability of Pseudomonas aeruginosa in Industrial Effluent. Appl. Microbiol. Lett. $28: 76-80$.

Garbisu, C., Alkorta, T., Llama, M.J., Serra, J.L. 1998. Aerobic Chromate Reduction by Bacillus subtilis. Biodegradation 9: 133-141

Holt, J.G., Krieg, N.R., Sneath, P.H.A., Staley, J.T. and Williams, S.T. 1994. Bergey's Manual of Determinative Bacteriology. $9^{\text {th }}$ eds. Williams \& Wilkins, USA : 562.

Hughes, M.N. and Poole, R.K. 1989. Metal and Microorganism, Chapman and Hall, London, USA p: $264-268$

Ishibashi, Y., Cervantes, C. and Silver, S. 1990. Chromium Reduction in Pseudomonas putida. Appl. Environ. Microbiol. 56: 2268 - 2270.

Kiefer, N. 2000. Mechanisms of Microbiology Metal Resistances. Dublin City- School of Biotechnology.

Krauter, P., Martinelli, R., Williams, K. and Martin, S. 1996. Removal of Cr(VI) from Ground Water by Sacharomyces cereviciae. Biodegradation 7: $277-286$.

McLean, J.S., Beveridge, T.J. and Phipps, D. 1999. Isolation and Characterization of a Chromium-Reducing Bacterium from a Chromate Copper Arsenate Contaminated Site. Appl. Environ. Microbiol. 2: 611 - 619.

Ohtake, H., Cervantes, C. and Silver, S. 1987. Decrease Chromate Uptake in Pseudomonas flourescens Carrying a Chromate Resistens Plasmid, J. Bacterial. 169: 3853 - 3856. 
Park, C.H., Keyhan, M., Wielinga, B., Fendorf, S. and Martin, A. 2000. Purification to Homogeneity and Characterization of a Novel Pseudomonas putida Chromate Reductase. Appl. Environ. Microbiol. 66: 1788 - 1795 .

Peitzsch, N., Eberrz, G. and Nies, D.H. 1998. Alcaligenes eutrophus as a Bacterial Chromate Sensor. Appl. Environ. Microbiol. 64: 453 - 458.

Renee, A.R. and Griffiths, J.M. 1993. Basic Biochemical Method. $2^{\text {nd }}$ Ed. Wiley-Liss.

Shen, H. and Wang, Y.T. 1993. Characterization of Enzymatic Reduction of Hexavalent Chromium by Escherichia coli ATCC 33456. App. Environ. Microbiol. 59(11): 3771-3777.

Wang, P.C., Muri, T., Toda, K. and Olitake, H. 1990. Membrane Associated Chromate Reductase Activity from Enterobacter cloacae. $J$. Bacteriology. 172: 1670 - 1672. 